\title{
Alanine Scan of [L-Dap2]Ramoplanin A2 Aglycon: Assessment of the Importance of Each Residue
}

\author{
Joonwoo Nam, Dongwoo Shin, Yosup Rew, and Dale L. Boger ${ }^{*}$ \\ Department of Chemistry and the Skaggs Institute for Chemical Biology, The Scripps Research \\ Institute, 10550 North Torrey Pines Road, La Jolla, California 92037
}

\section{Abstract}

In efforts that define the importance of each residue and that identify key regions of the molecule, an alanine scan of the ramoplanin A2 aglycon, a potent antibiotic that inhibits bacterial cell wall biosynthesis, is detailed. As a consequence of both its increased stability (lactam vs lactone) and its "relative" ease of synthesis, the alanine scan was conducted on [Dap $\left.{ }^{2}\right]$ ramoplanin A2 aglycon which possesses antimicrobial activity equal to or slightly more potent than ramoplanin A2 or its aglycon. Thus, 14 key analogues of the ramoplanin A2 aglycon, representing a scan of residues 3-13, 15, and 17, were prepared enlisting a convergent solution-phase total synthesis that consolidated the effort to a manageable level. The antimicrobial activity of the resulting library of analogues provides insight in the importance and potential role of each residue of this complex glycopeptide antibiotic.

\section{Introduction}

Due to the overuse of broad spectrum antibiotics in medicine and agriculture, the increasing frequency of bacterial resistance to existing drugs presents a serious threat to public health. ${ }^{1}$ Such growing concerns have increased with the recent reports of the emergence of multi-drug resistant organisms including methicillin-resistant Staphylococcus aureus (MRSA) or methicillin-resistant enterococci that exhibit a reduced vancomycin susceptibility. ${ }^{2}$ As a result, it has become increasingly important to identify new antibiotics that can replace vancomycin as the antibiotic of last resort for such resistant bacterial infections.

Ramoplanin is a lipoglycodepsipeptide first isolated from the fermentation broths of Actinoplanes sp. ATCC 33076 in 1984 (Figure 1). ${ }^{3}$ The ramoplanin complex, which consists of three closely related compounds $\mathbf{1 - 3},{ }^{4}$ was found to be $2-10$ times more active than vancomycin against Gram-positive bacteria (500 strains), and maintains full activity against vancomycin-resistant enterococci (VRE, MIC $=0.5 \mu \mathrm{g} / \mathrm{mL}$ ) and all known strains of MRSA. 5 Although the mechanism of action of ramoplanin is not yet fully defined, it is a promising drug candidate for vancomycin-resistant bacterial infections since it is known to function in a unique manner. ${ }^{6}$ Both antibiotics inhibit bacterial cell wall biosynthesis, but vancomycin prevents cell wall cross-linking by primarily inhibiting the late stage transpeptidase-catalyzed step by binding to its substrate D-Ala-D-Ala at the terminus of peptidoglycan precursors, ${ }^{7}$ whereas ramoplanin inhibits the earlier stage intracellular glycosyltransferase (MurG) and the more accessible extracellular transglycosylase (PBP1b)-catalyzed steps by binding their substrates Lipid I and II, thereby precluding maturation of the bacterial cell wall. 6,8 Consequently, no cross-resistance of ramoplanin with existing antibiotics, including vancomycin, has yet been observed. Currently, ramoplanin is in phase III clinical trials for topical, nasal, and GI infections. ${ }^{5,9}$ However, the therapeutic applications of ramoplanin are 
limited because of its poor pharmacokinetics: it is not orally absorbed and it is not stable in plasma due to rapid hydrolysis of the labile lactone.

Ramoplanin A1-A3 consists of a 49-membered ring composed of 17 amino acids including 12 unnatural amino acids and 7 possessing the D-configuration. The initial structure of ramoplanin was disclosed in 1989 and the three compounds that make up the ramoplanin complex differ only in the lipid side chains attached to the $\mathrm{Asn}^{1} \mathrm{~N}$-terminus. ${ }^{4}$ Originally, the two double bonds in the three different acyl groups were assigned the cis-cis stereochemistry $4 \mathrm{a}$ and this has since been corrected to be cis-trans. ${ }^{10}$ The $C$-terminal 3chloro-4-hydroxyphenylglycine $\left(\mathrm{Chp}^{17}\right)$ forms a lactone bond with the hydroxy group of $\beta$ hydroxyasparagine $\left(\mathrm{HAsn}^{2}\right.$ ). In 1991, the structure of ramoplanose (4) was disclosed by Williams and coworkers and its composition was identical to ramoplanin A2 except for the branched mannose trisaccharide (vs mannose disaccharide) at $\mathrm{Hpg}^{11}$ and the stereochemistry of the acyl side chain (cis, trans- vs cis, cis-7-methyloctadi-2,4-enoic acid). ${ }^{11}$ Kruz and Guba subsequently corrected the olefin stereochemistry of ramoplanin A2 as cis-trans by 2D NMR in 1996. ${ }^{10}$ They also established the $\mathrm{Hpg}^{6}$ and $\mathrm{Hpg}^{7}$ absolute stereochemistry and found that the solution conformation consists of two antiparallel $\beta$-strands (HAsn ${ }^{2}-\mathrm{D}-\mathrm{Hpg}^{7}$ and DOrn ${ }^{10}-$ Gly $^{14}$ ) stabilized by six transannular H-bonds and a cluster of hydrophobic aromatic side chains (D-Hpg ${ }^{3}, \mathrm{Phe}^{9}$, and $\mathrm{Chp}^{17}$ ) providing a U-shape topology to the $\beta$-sheet with a reverse $\beta$-turn $\left(a \mathrm{Thr}^{8}-\mathrm{Phe}^{9}\right)$ at one end and a more flexible connecting loop $\left(\mathrm{Leu}^{15}-\mathrm{Chp}^{17}\right)$ at the other end in the solution structure.

Enduracidin A and B are additional members of ramoplanin family that have been employed as feed additives and are known to inhibit Gram-positive bacterial cell wall biosynthesis 12 by the same mechanism as the ramoplanins $12 \mathrm{f}$ (Figure 2 ). The enduracidins and ramoplanins share a high degree of structural similarity including two-antiparallel $\beta$-strands and a conserved D$\mathrm{Hpg}^{3}-a \mathrm{Thr}^{8}$ region thought to be important for Lipid I and II recognition and binding. Moreover, many of the remaining residues in the enduracidins and ramoplanins are identical $\left(\mathrm{Hpg}^{11}, \mathrm{Gly}^{14}, \mathrm{D}-\mathrm{Ala}^{16}\right)$ or represent conservative structural departures (D-Ser ${ }^{12}$ vs D$a \mathrm{Thr}^{12}$, $\mathrm{Dpg}^{13} \mathrm{vs} \mathrm{Hpg}^{13}, \mathrm{Hpg}^{17} \mathrm{vs} \mathrm{Chp}^{17}$, and $\mathrm{Thr}^{2} \mathrm{vs} \mathrm{HAsn}^{2}$ ). Even some of the significant departures $\left(\mathrm{Cit}^{9}\right.$ vs $\mathrm{Phe}^{9}$ and D-End ${ }^{10}$ vs D-Orn ${ }^{10}$ ) represent changes that maintain the stereochemical and potential functional features (D-End ${ }^{10}$ vs D-Orn ${ }^{10}$ ) of the ramoplanins. Recently, Marazzi and coworkers disclosed a solution phase conformation of the enduracidins determined by NMR exhibiting only subtle structural differences between the enduracidins and ramoplanins. ${ }^{13}$ The enduracidins do not contain a di- or trisaccharide at $\mathrm{Hpg}^{11}$ and the lipid side chains are longer than those found in the ramoplanins. Enduracidin includes an additional basic residue at End ${ }^{15}$ (vs Leu ${ }^{15}$ ) and an acidic residue at $\mathrm{Asp}^{1}$ (vs Asn ${ }^{1}$ ) that are proximal and engaged in a transannular salt bridge, as well as a flexible side chain at the $\mathrm{Cit}^{9}$, which is exposed to the solvent $\left(\mathrm{H}_{2} \mathrm{O}-\mathrm{DMSO}-d_{6}, 4: 1\right)$, whereas ramoplanin incorporates a hydrophobic side chain at $\mathrm{Phe}^{9}$ forming a well-packed hydrophobic core along with other aromatic side chains (D-Hpg ${ }^{3}, \mathrm{Chp}^{17}$ ) and the lipid side chain. ${ }^{10}$ The net result being that the characteristic ramoplanin hydrophobic core is disrupted within the enduracidins. The significance of this difference is yet to be defined and it is not reflected in different transglycosylase inhibition kinetics. ${ }^{12 \mathrm{f}}$ Although less well characterized, janiemycin represents an additional member of ramoplanin family. 14

In 2002, we reported the first total synthesis of the ramoplanin A2 and ramoplanose aglycon (5) confirming the assigned structure. ${ }^{15}$ Three key subunits composed of D-Hpg ${ }^{3}-\mathrm{Phe}^{9}$ (subunit A), Leu ${ }^{15}-$ Asn $^{1}$ (subunit B), and D-Orn ${ }^{10}-$ Gly $^{14}$ (subunit C) were synthesized, sequentially coupled, and cyclized in a solution phase approach to the 49-membered macrocyclic core of ramoplanin. Two macrocyclization sites, Phe ${ }^{9}-\mathrm{D}-\mathrm{Orn}^{10}$ and Gly ${ }^{14}$ $\mathrm{Leu}^{15}$, were examined that maximize the convergency of the synthesis, minimize the use of protecting groups, prevent late stage opportunities for racemization of carboxylate-activated 
phenylglycine-derived residues, and benefit from a $\beta$-sheet preorganization of an acyclic substrate for ring closure. ${ }^{16}$ Macrocyclization at the Phe ${ }^{9}-\mathrm{D}-\mathrm{Orn}{ }^{10}$ site additionally benefits from closure at the corner of a $\beta$-turn incorporating a $\mathrm{D}$-amine ${ }^{17}$ while the alternative closure at the Gly ${ }^{14}-\mathrm{Leu}^{15}$ site represents a non-hindered glycine site incapable of racemization. Additional keys to the success of the approach were the choice of a SES protecting group for $\mathrm{Orn}^{4} / \mathrm{Orn}^{10}$ and Fmoc protection for Asn ${ }^{1}$ furnishing orthogonal protecting groups to Boc, $\mathrm{Cbz}$, and benzyl ester deprotections yet capable of sequential and selective removal in the presence of the unstable depsipeptide ester bond. Deliberate final stage incorporation of the Asn ${ }^{1}$ lipid side chain provided late stage access to all three ramoplanins as well as side chain analogues of the aglycons. As such, the total synthesis of the two minor components of the ramoplanin complex (A1 and A3) was achieved confirming a reassigned cis-trans stereochemistry for the lipid side chains. ${ }^{18}$

This approach has since been extended to the synthesis of two key analogues of ramoplanin containing an amide linkage in place of the labile ester between HAsn ${ }^{2}$ and $\mathrm{Chp}^{17}$ in which $\mathrm{HAsn}^{2}$ was replaced with L-2,3-diaminopropionic acid (Dap) or L-2,4-diaminobutyric acid (Dab). ${ }^{19}$ The two derivatives are both much more stable and synthetically more accessible than the natural ramoplanin aglycon. In a subsequent mechanistic analysis of these analogues, both amide linkage substitutions as well as removal of the lipid chain did not affect Lipid II binding indicating that the residue 2 modifications and the acyl side chain do not play an important role in substrate recognition and binding. ${ }^{20}$ However, the antimicrobial activities of the $\mathrm{Dab}^{2}$ analogue and compounds containing truncated side chains were not comparable to those of ramoplanin or the $\mathrm{Dap}^{2}$ analogue. The ring expanded 50-membered $\mathrm{Dab}^{2}$ analogue, but not the 49-membered $\mathrm{Dap}^{2}$ analogue, was found to aggregate extensively in aqueous buffer where its increased conformational flexibility perhaps permits the $\beta$-strands in the molecule to associate in an intermolecular manner (aggregation), ${ }^{20}$ whereas the lipid side chain presumably helps ramoplanin localize to the bacterial cell membrane. ${ }^{20}$

In 1998, Brötz et al. reported the first direct evidence that ramoplanin binds to a substrate involved in peptidoglycan biosynthesis. ${ }^{21}$ In 2000 , Walker and coworkers showed that ramoplanin inhibits the transglycosylation step of peptidoglycan biosynthesis by binding to Lipid II. ${ }^{6 \mathrm{~d}}$ Shortly following that, insights into the interaction between ramoplanin A2 and a peptidoglycan precursor (Park's nucleotide) were disclosed by McCafferty using NMR studies suggesting that the octapeptide sequence (D-Hpg $\left.{ }^{3}-\mathrm{D}-\mathrm{Orn}^{10}\right)$, ${ }^{\mathrm{a}}$ which is highly conserved among ramoplanins and enduracidins, constitutes the substrate recognition domain. Contemporary with these studies, inhibition kinetic studies $6 \mathrm{~g}$ and NMR titration experiments $6 \mathrm{f}$ performed by Walker and coworkers suggest that the inhibitory species binds with a stoichiometry of 2:1 ramoplanin:Lipid II and in a second NMR study, Lo et al. observed that ramoplanin A2 exists as a mixture of monomer and dimer in methanol. $6 \mathrm{e}$ This latter series of studies led Walker to propose that Lipid II may bind in a cleft formed by the dimerization of two ramoplanin molecules and defined the dimer interface region as D-Orn ${ }^{10}-\mathrm{Hpg}^{13}$.

Herein, we report an alanine scan of ramoplanin A2 aglycon and the resulting antimicrobial properties of the derivatives in efforts to define the importance of the individual residues and to identify key regions of the molecule. ${ }^{22}$ As a consequence of its "relative" ease of synthesis and its resulting stability (lactam vs lactone), the alanine scan was conducted on the [Dap $\left.{ }^{2}\right]$ ramoplanin A2 aglycon (6) which possesses antimicrobial activity equal to or slightly more potent than the authentic ramoplanin A2 aglycon itself (Figure 3). ${ }^{19}$ Notably, the efforts constitute a scan of residues $3-13,15$, and 17 conducted implementing a convergent solutionphase total synthesis of the 14 key analogues. 


\section{Chemistry}

Following the completion of the total synthesis of the natural product aglycons 15,18 and the identification of an active and stable amide (vs depsipeptide ester) template, [Dap ${ }^{2}$ ]ramoplanin A2 aglycon, ${ }^{19}$ we initiated and herein report an alanine scan of the ramoplanin A2 aglycon enlisting [Dap ${ }^{2}$ ramoplanin $\mathrm{A} 2$ as the template. These efforts include a full alanine scan of the subunit A (D-Hpg $\left.{ }^{3}-\mathrm{Phe}^{9}\right)$ and $\mathrm{C}\left(\mathrm{D}-\mathrm{Orn}^{10}-\mathrm{Gly}^{14}\right)$ which contain the putative substrate recognition domain $\left(\mathrm{D}-\mathrm{Hpg}^{3}-\mathrm{D}-\mathrm{Orn}^{10}\right.$ ) proposed by McCafferty, ${ }^{8 \mathrm{a}}$ the dimer interface region $\left(\mathrm{D}-\mathrm{Orn}^{10}{ }^{-} \mathrm{Hpg}^{13}\right.$ ) defined by Walker, ${ }^{6 \mathrm{e}}$ and D-Orn ${ }^{4}$ and D-Orn ${ }^{10}$ which have been established to be important to the biological properties of ramoplanin. $6 \mathrm{f}, 8 \mathrm{a}, 15 \mathrm{~b}, 19$ Selective semisynthetic modifications of D-Orn ${ }^{4}$ or D-Orn ${ }^{10}$ are notorious for their low yields or poor selectivity. Consequently, the identification of the modified site is difficult and the results derived from their examination have not been entirely conclusive. ${ }^{4 c-e}$ Therefore, the site specific incorporation of $\mathrm{D}-\mathrm{Ala}^{4}$ and $\mathrm{D}-\mathrm{Ala}^{10}$ by the synthetic methods detailed herein unambiguously address these issues. In addition and to more clearly elucidate the role of the chlorine substitution at $\mathrm{Chp}^{17}$, a $\mathrm{Hpg}^{17}$ as well as $\mathrm{Ala}^{17}$ analogue was prepared.

The synthesis and assembly of three key subunits were facilitated by the convergent nature of the solution-phase approach (Figure 3). For example, each change within the A subunit utilized the common $\left[\mathrm{Dap}^{2}\right] \mathrm{B}$ and $\mathrm{C}$ subunits for completion of the synthesis and this expedited the parallel synthesis of the library. Similarly, each of the subunits A, B, and C was also assembled in a convergent fashion (e.g., $\mathrm{Ala}^{3}$ through $\mathrm{Ala}^{5}$ were prepared by coupling the modified tripeptide to a common $\mathrm{Hpg}^{6}-\mathrm{Phe}^{9}$ tetrapeptide), and this consolidated the work to a manageable level reducing the complexity of the syntheses and number of new intermediates. Thus, each residue analogue required at most five coupling reactions to assemble the linear peptide, a macrocyclization, the side chain introduction ( 2 steps), and a final global deprotection (9 operations total) enlisting unmodified subunits used in the synthesis of [Dap $\left.{ }^{2}\right]$ ramoplanin A2 aglycon.

\section{Synthesis of the A subunit Ala derivatives: heptapeptide D-Hpg ${ }^{3}-\mathrm{Phe}^{9}$}

The seven synthetic targets of the alanine-substituted subunit A (8-14) and details of the preparation of the $\left[\mathrm{Ala}^{5}\right]$ analogue $(\mathbf{1 0})$ are summarized in Scheme $1 .{ }^{23}$ Following the approach defined for synthesis of authentic subunit A (7), heptapeptides 8-14, which contains all but $\mathrm{Orn}^{10}$ of the putative $\mathrm{Hpg}^{3}-\mathrm{Orn}^{10}$ recognition domain, were assembled from the D-Hpg ${ }^{3}$-D$a \mathrm{Thr}^{5}$ tripeptide and $\mathrm{Hpg}^{6}-\mathrm{Phe}^{9}$ tetrapeptide. ${ }^{15} \mathrm{In}$ turn, the tripeptide for $\mathbf{1 0}$ was obtained by the coupling of Boc-D-Hpg ${ }^{3}-\mathrm{D}-\mathrm{Orn}^{4}$ (SES)-OH and H-D-Ala-OBn (72\%). Benzyl ester hydrogenolysis followed by coupling with $\mathrm{H}-\mathrm{Hpg}^{6}-\mathrm{D}-\mathrm{Hpg}^{7}-a \mathrm{Thr}^{8}-\mathrm{Phe}^{9}-\mathrm{OBn}$ gave the heptapeptide $10(48 \%)$. In similar fashion, the remainder of the alanine-substituted A subunits were prepared (Supporting Information).

\section{Synthesis of the $\mathbf{C}$ subunit Ala derivatives: pentapeptide D-Orn ${ }^{10}-G_{1 y}{ }^{14}$}

The preparation of the pentapeptide $\mathbf{1 5},{ }^{15}$ which contains the entire dimer interface domain, $6 \mathrm{e}$ and the synthetic alanine-substituted $C$ subunits (16-19) are summarized in Scheme 2 along with details of the key $\left[\mathrm{Ala}^{10}\right]$ derivative. Coupling of HCl-H-L-Hpg ${ }^{11}-\mathrm{D}-a \mathrm{Thr}^{12}-\mathrm{OBn}$ with Boc-D-Ala-OH provided the tripeptide in $99 \%$ yield. Benzyl ester deprotection and coupling with H-L-Hpg ${ }^{13}$-Gly ${ }^{14}-\mathrm{OBn}$ gave pentapeptide $\mathbf{1 6}$ (90\% yield). The synthesis of remaining alanine-substituted $\mathrm{C}$ subunits proceeded similarly (Supporting Information). Since residue 14 is glycine, its replacement with an alanine was not conducted.

\section{Synthesis of the B subunit derivatives: pentapeptide [L-Dap ${ }^{2}$ B}

Within the B subunit, residue 2 was fixed as the simplified and stable Dap ${ }^{2}$ where the side chain linkage is attached to the coupled and similarly unmodified Asn ${ }^{1}{ }^{19}$ Additionally, residue 
16 already constitutes a D-Ala and it was not further modified. Rather, our interest focused on Leu ${ }^{15}$ as well as $\mathrm{Chp}^{17}$ which was replaced with $\mathrm{Hpg}^{17}$ to directly assess the role of the unusual chloride substituent as well as $\mathrm{Ala}^{17}$ (Scheme 3). The modified pentapeptide subunit $\mathbf{2 3}$, incorporating the $\mathrm{Hpg}^{17}$ (or $\mathrm{Ala}^{17}$ for 22 ) residue and the $\mathrm{Dap}^{2}$ amide, was obtained from an intermediate tripeptide which in turn was prepared by coupling Boc-Leu ${ }^{15}-\mathrm{D}-\mathrm{Ala}^{16}{ }_{-} \mathrm{OH}$ with $\mathrm{HCl} \cdot \mathrm{H}-\mathrm{Hpg}^{17}$-OBn (EDCI, HOAt, $\mathrm{NaHCO}_{3}, 20 \%$ DMF- $\mathrm{CH}_{2} \mathrm{Cl}_{2}, 0{ }^{\circ} \mathrm{C}, 20 \mathrm{~h}$ ) followed by deprotection of the benzyl ester $\left(\mathrm{H}_{2}, 10 \% \mathrm{Pd} / \mathrm{C}, \mathrm{MeOH}, 25^{\circ} \mathrm{C}, 20 \mathrm{~min}, 100 \%\right)$. Fmoc$\mathrm{Dap}^{2}\left(\mathrm{NH}_{2} \cdot \mathrm{HCl}\right)-\mathrm{OBn}$ obtained from Fmoc-Dap ${ }^{2}(\mathrm{Boc})-\mathrm{OH}(\mathrm{HCl}-\mathrm{EtOAc})$ was coupled with this tripeptide using DEPBT (3-(diethoxyphosphoryloxy)-1,2,3-benzotriazin-4(3H)-one) ${ }^{23}$ $\left(\mathrm{NaHCO}_{3}, \mathrm{DMF}, 0{ }^{\circ} \mathrm{C}, 1 \mathrm{~h}\right.$, then $\left.25^{\circ} \mathrm{C}, 52 \mathrm{~h}, 100 \%\right)$ to give a single diastereomer of the corresponding tetrapeptide with no detectable racemization of the sensitive $\mathrm{Hpg}^{17}$ residue. Fmoc removal $\left(\mathrm{Bu}_{4} \mathrm{NF}, i\right.$-PrOH, DMF, $25^{\circ} \mathrm{C}, 1 \mathrm{~h}$, sonication), coupling the free amine with Fmoc-Asn(Trt)-OH (EDCI, HOAt, DMF, $0{ }^{\circ} \mathrm{C}, 48 \mathrm{~h}, 61 \%$ for 2 steps), and benzyl ester hydrogenolysis $\left(\mathrm{H}_{2}, 10 \% \mathrm{Pd} / \mathrm{C}, \mathrm{EtOH}, 25^{\circ} \mathrm{C}, 45 \mathrm{~min}, 100 \%\right)$ provided 23a. ${ }^{19}$ The original pentapeptide subunit $\mathrm{B}$ and the simplified [ $\mathrm{Dap}^{2}$ ] B subunit $\mathbf{2 0}$ were found to be sensitive to the benzyl ester deprotection step potentially generating mixtures with a contaminate dechlorinated side product if not closely monitored. In an effort to take advantage of this observation and to reduce the number of synthetic steps for the preparation of 23a, direct dechlorination of the [Dap $\left.{ }^{2}\right]$ B subunit 20 or [ $\mathrm{Dap}^{2}$ ]ramoplanin A2 aglycon itself under various conditions were examined. However, the rate of dechlorination was too slow and the approach proved to be impractical.

\section{Synthesis of [Dap ${ }^{2}$, Ala $\left.{ }^{\mathrm{m}}\right]$ ramoplanin A2 Aglycon}

The convergent strategy developed for the total synthesis of the ramoplanin and [Dap $\left.{ }^{2}\right]$ ramoplanin A2 aglycons was utilized for the preparation of the alanine-substituted [Dap ${ }^{2}$ ] ramoplanin A2 aglycon analogues. ${ }^{19}$ For example, assemblage of the alaninesubstituted subunit A analogues $(\mathbf{8}-\mathbf{1 4})$ required coupling with the common unmodified B and C subunits and maximized the convergent nature of the synthesis. Representative of the final stages of the analogue preparations, the synthesis of $\left[\mathrm{Dap}^{2}, \mathrm{D}-\mathrm{Ala}^{3}\right]$ ramoplanin $\mathrm{A} 2$ aglycon begins with the treatment of $\mathbf{8}$ with $4 \mathrm{~N} \mathrm{HCl}$-dioxane followed by coupling of resulting amine with the $\mathrm{B}$ subunit carboxylic acid 20a to provide $\mathbf{8 b}$ without competitive $\beta$-elimination (Scheme 4). An excess of 20a was employed to consume all 8a which proved difficult to remove from the product enlisting either an acid wash or chromatography. Boc removal of $\mathbf{8 b}$ under mild conditions ( $B$-bromocatecholborane $\equiv \mathrm{BCB}, \mathrm{CH}_{3} \mathrm{CN}, 0^{\circ} \mathrm{C}, 3 \mathrm{~h}$ ) which do not affect the Asn ${ }^{1}$ trityl group and successive washing of reaction mixture with aqueous $\mathrm{NaHCO}_{3}$, aqueous $1 \mathrm{~N} \mathrm{HCl}$, and water gave the corresponding amine. ${ }^{19}$ The resulting amine was then coupled with the unmodified subunit C (15a) to yield 8c. Successive Boc removal, benzyl ester hydrogenolysis and macrocyclization provided the cyclic peptide core 8d in superb yield attributable the $\beta$-sheet preorganization of the cyclization substrate as well as closure at a Damine terminus. ${ }^{17}$ Fmoc removal under specially developed conditions ( 8 equiv of $\mathrm{Bu}_{4} \mathrm{NF}$, 10 equiv of $i$ - $\mathrm{PrOH}, \mathrm{DMF}, 25^{\circ} \mathrm{C}, 1 \mathrm{~h}$ ), acyl side chain introduction and final global deprotection ( HF, anisole, $0{ }^{\circ} \mathrm{C}, 90 \mathrm{~min}$ ) yielded [ $\mathrm{Dap}^{2}$, D-Ala ${ }^{3}$ ramoplanin $\mathrm{A} 2$ aglycon $(\mathbf{8 g}) .{ }^{15} \mathrm{In}$ similar manner, each of the ramoplanin A2 aglycon analogues was synthesized and details of their synthesis and their intermediates are provided in the Supporting Information. The final products were purified by reverse-phase HPLC to provide homogeneous materials that were used for characterization and the biological evaluation of the final products. However, it is notable that the final products were obtained in purities ranging from $46-91 \%$ (avg. $=73 \%$, see Supporting Information) even before this final purification. The ${ }^{1} \mathrm{H}$ NMR spectroscopic properties of each of the analogues did not reveal a loss of conformational rigidity that might contribute to a change or loss of antimicrobial activity and only $\mathrm{Ala}^{8}, \mathrm{Ala}^{10}, \mathrm{Ala}^{11}$, and most notably Ala ${ }^{17}$ exhibited slightly less crisp spectra that might be attributable to a conformational heterogeneity (line broadening). 


\section{A 48-membered ramoplanin A2 aglycon analogue}

One of the more successful structural modifications of the ramoplanin aglycon has been the replacement of L-HAsn ${ }^{2}$ with L-Dap ${ }^{2}$ simplifying the synthesis and removing the hydrolysis labile depsipeptide ester. Surprisingly, the analogous replacement with L-Dab ${ }^{2}$, which results in a ring expansion to a 50-membered ring, resulted in a $>100$-fold loss in antimicrobial activity and provided an analogue with a propensity for aggregation in aqueous buffer. As a consequence, we now examined the ring contracted 48-membered analogue $\mathbf{2 5 g}$ incorporating a D-Orn ${ }^{2}$ in place of L-HAsn ${ }^{2}$ where the side chain also incorporates an amine for lipid side chain attachment removing the need for Asn ${ }^{1}$ (Scheme 5). The simplified B subunit 25a was prepared and sequentially coupled with the authentic A (7a) and C (15a) subunits (Scheme 5). To our disappointment, all efforts to promote the macrocyclization of the linear peptide 25c following $\mathrm{C}$ - and $\mathrm{N}$-terminus deprotection failed to provide the macrocyclic peptide $\mathbf{2 5 d}$. Presumably, the decreased flexibility of $\mathbf{2 5 c}$ resulting from deleting the one methylene is sufficient to preclude macrocyclization. These observations along with the behavior of the 50membered [Dap ${ }^{2}$ ]ramoplanin A2 aglycon underscores the special role residue 2 plays in conveying antimicrobial activity to the compounds and highlights how remarkable the stable L-Dap ${ }^{2}$ for L-HAsn² substitution is.

\section{Antimicrobial Activity}

The results of the antimicrobial assay of the analogues against $S$. aureus alongside the ramoplanin complex $(\mathrm{MIC}=0.19 \mu \mathrm{g} / \mathrm{mL})$ and $\left[\mathrm{Dap}^{2}\right] \mathrm{ramoplanin} \mathrm{A} 2$ aglycon $(\mathbf{6}, \mathrm{MIC}=0.07$ $\mu \mathrm{g} / \mathrm{mL}$ ) are summarized in Figure 4. Analogous to observations first reported for [Dap ${ }^{2}$ ] ramoplanin A2 aglycon (6) upon its initial disclosure, 19 it proved to be 2-3 fold more potent than the natural ramoplanin complex and slightly more active than the ramoplanin A2 aglycon. 19,20 Perhaps the most important of the comparisons to highlight first are the activities of the $\mathrm{Ala}^{4}$ and $\mathrm{Ala}^{10}$ analogues probing the importance of $\mathrm{Orn}^{4}$ and $\mathrm{Orn}^{10}$. Semisynthetic modifications of these sites have indicated that both contribute significantly to ramoplanin's activity, but their relative importance and potential role remained unclear. $8 \mathrm{a}, 6 \mathrm{f}, 15 \mathrm{~b}, 19$ Consistent with Walker's observations with such semisynthetic derivatives, $6 \mathrm{f}$ the $\mathrm{Ala}^{10}$ analogue $16 \mathrm{~g}(\mathrm{MIC}=38 \mu \mathrm{g} / \mathrm{mL})$ proved to be 540 -fold less active than $\mathbf{6}$, whereas the $\mathrm{Ala}^{4}$ analogue $9 \mathrm{~g}\left(\mathrm{MIC}=3.1 \mu \mathrm{g} / \mathrm{mL}\right.$ ) was 45 -fold less potent. This clearly indicates that $\operatorname{Orn}^{10}$ is essential to the activity of ramoplanin and plays a much more fundamental role than $\mathrm{Orn}^{4}$, although both $\mathrm{Ala}^{10}$ and $\mathrm{Ala}^{4}$ are among the least effective of the Ala analogues examined.

Within the remainder of the putative Lipid II binding domain proposed by McCafferty $\left(\mathrm{Hpg}^{4}-\mathrm{Orn}^{10}\right),{ }^{8 \mathrm{a}}$ the additional largest impacts on activity were observed with D-Ala ${ }^{3}$ (vs D$\left.\mathrm{Hpg}^{3}, \mathrm{MIC}=5.2 \mu \mathrm{g} / \mathrm{mL}\right), \mathrm{D}_{-\mathrm{Ala}^{7}}\left(\mathrm{vs} \mathrm{D}-\mathrm{Hpg}^{7}, \mathrm{MIC}=3.7 \mu \mathrm{g} / \mathrm{mL}\right)$, and Ala ${ }^{8}\left(\mathrm{vs} a \mathrm{Thr}^{8}\right.$, MIC $=2.5 \mu \mathrm{g} / \mathrm{mL}$ ) representing 75 -fold, 50-fold, and 35-fold losses in antimicrobial activity, respectively. Thus, both $\mathrm{D}-\mathrm{Hpg}^{3}$ and D-Hpg ${ }^{7}$ proved more significant than D-Orn ${ }^{4}$, and $a \mathrm{Thr}^{8}$ approaches this level of importance. Notably, the importance of $a \mathrm{Thr}^{8}$ is unique among the three $a \mathrm{Thr}$ sites in ramoplanin, and each of the remaining D-Ala/D- $a \mathrm{Thr}^{8}$ substitutions (residues 5 and 12) resulted in $\leq 10$-fold reductions in activity. Surprisingly, $\mathrm{Ala}^{6}$ (vs $\mathrm{Hpg}^{6}$, $\mathrm{MIC}=0.9 \mu \mathrm{g} / \mathrm{mL})$ as well as D-Ala ${ }^{5}\left(\mathrm{vs} \mathrm{D}-a \mathrm{Thr}^{5}, \mathrm{MIC}=0.16 \mu \mathrm{g} / \mathrm{mL}\right)$ central to this region had the least impact on ramoplanins properties resulting in only 10 -fold and 2-fold reductions in antimicrobial activity. In fact, $\mathrm{Hpg}^{6}$ proved to be the least important of the phenylglycines imbedded in the ramoplanin structure and each of the Ala/Hpg substitutions elsewhere resulted in $>20$-fold reductions in activity, and the $\mathrm{Ala}^{5}$ analogue [ $\left.\mathrm{Dap}^{2}, \mathrm{Ala}^{5}\right]$ ramoplanin A2 aglycon still proved to be slightly more active than the natural ramoplanin complex despite its 2 -fold reduction in activity versus 6 .

The $\mathrm{Ala}^{9}$ analogue $(\mathrm{MIC}=0.6 \mu \mathrm{g} / \mathrm{mL})$ with modification of $\mathrm{Phe}^{9}$ resulted in a modest $8-9$ fold reduction in antimicrobial activity despite its role in capping the hydrophobic core and 
important location at the corner of a $\beta$-turn in ramoplanins structure adjacent to D-Orn ${ }^{10}{ }^{10}$ Given that the $\mathrm{Orn}^{10}$ importance almost certainly arises as a consequence of a key stabilizing binding interaction with the diphosphate central to the structure of Lipid I and II, ${ }^{6,8}$ it is surprising that the adjacent residue $\mathrm{Phe}^{9}$, unlike $\mathrm{Hpg}^{11}$, would have such a modest effect. Nonetheless, it is consistent with the departure in structure observed with the enduracidins which possess a solvent accessible $\mathrm{Cit}^{9}$ residue and suggests this may represent a useful modification site for further functionalization or conjugation efforts.

The Ala analogues spanning the dimerization domain defined by Walker and observed in $\mathrm{MeOH}\left(\mathrm{Hpg}^{11}-\mathrm{Gly}^{14}\right),{ }^{6 \mathrm{e}}$ which resides adjacent to the key $\mathrm{Orn}^{10}$ and transannular to the putative Lipid II recognition domain defined by McCafferty, ${ }^{\mathrm{a}}$ proved especially interesting. Each of the Ala substitutions resulted in a $\geq 10$-fold reduction in antimicrobial activity with that of $\mathrm{Ala}^{11}$ ( $\mathrm{vs} \mathrm{Hpg}^{11}, \mathrm{MIC}=2.5 \mu \mathrm{g} / \mathrm{mL}$ ) being the greatest ( 35 -fold), followed by $\mathrm{Ala}^{13}$ (vs $\mathrm{Hpg}^{13}$, MIC $=1.4 \mu \mathrm{g} / \mathrm{mL}, 20$-fold) and D-Ala ${ }^{12}$ (vs D- $a \mathrm{Thr}^{12}$, MIC $=0.7 \mu \mathrm{g} / \mathrm{mL}, 10$-fold). In addition to illustrating a significant role that residues in this potential dimerization domain may play in ramoplanin's interaction with its biological target(s), it also defines D- $a \mathrm{Thr}^{12}$ as the residue at which to probe such roles. In this regard, it is interesting to note that the enduracidins incorporate a D-Ser ${ }^{12}$ in place of D- $a \mathrm{Thr}^{12}$ and that Walker's ramoplanin dimer structure established by NMR places its residue 12 hydroxyls within $3.87 \AA$ of one another on the same face of the dimerization interface. Clearly, this represents a unique residue whose functionalization, deliberate dimerization, or conjugation may be exploited to probe mechanistic questions without perturbing the intrinsic structure of the ramoplanin monomer or dimer.

Finally, the examination of several additional analogues within the less well defined Leu ${ }^{15}$ Asn ${ }^{1}$ segment, which adopts a more flexible loop at one end of the ramoplanin structure and contains depsipeptide ester as well as the lipid side chain, has shed additional insights into its importance. Previously, we have shown that the lipid side chain is essential for antimicrobial activity (200-800 fold reductions), ${ }^{19,20}$ but does not impact Lipid II binding presumably serving to deliver or anchor ramoplanin to the bacterial cell wall. ${ }^{20}$ Additionally, L-Dap ${ }^{2}$ (49membered ring), but not L-Dab ${ }^{2}$ (50- membered ring), effectively replaces $\mathrm{HAsn}^{2}$ (49membered ring) providing a stable amide replacement for the labile depsipeptide ester. ${ }^{19,20}$ Herein, the extentions of this work to an attempted replacement with D-Orn ${ }^{2}$ resulting in a ring contracted 48-membered macrocyclic amide revealed that the macrocyclization ring closure failed to provide the core structure. The ease of 49-membered ring macrocyclization, the failure of the corresponding (more rigid) 48-membered ring closure, and the aggregation of the 50membered ring system, ${ }^{20}$ suggests a significant structural role for this corner of ramoplanin structure and highlights how special the properties of [Dap $\left.{ }^{2}\right]$ ramoplanin A2 aglycon are. Additionally, we probed the importance of the adjacent $\mathrm{Chp}^{17}$ residue in this region. Its replacement with $\mathrm{Hpg}^{17}$ representing the removal of the aromatic chlorine substituent had virtually no impact on the antimicrobial properties $\left(\mathrm{MIC}=0.09 \mu \mathrm{g} / \mathrm{mL}\right.$ ) ${ }^{24}$ Consistent with this lack of functional role for the chlorine substituent, the enduracidins incorporate $\mathrm{Hpg}^{17}$ in their structure at this site. More significantly, the $\mathrm{Ala}^{17}$ replacement for $\mathrm{Chp}^{17}$ with $\mathbf{2 2 g}$ (MIC $=0.3 \mu \mathrm{g} / \mathrm{mL}$ ) had a similar lack of effect in the antimicrobial activity resulting in only a modest 4-fold reduction in antimicrobial potency. Despite the apparent significance of the structural change, this Ala modification at residue 17 was among those that had the least effect of any of the Ala substitutions although it was among the residues including $\mathrm{Phe}^{9}$ that perturb the rigid solution conformation characteristic of ramoplanin. We have interpreted this behavior to suggest that it is only the stereochemistry at this center that might be important for its antimicrobial activity, and that residues 16-1, constituting a more flexible loop including a D$\mathrm{Ala}^{16}$ at one end of the antiparallel $\beta$-sheet, do not directly interact with the biological target Lipid I or II and do not play a direct functional role. However, $\mathrm{Phe}^{9}$ and $\mathrm{Chp}^{17}$ do stabilize the intrinsic solution structure of ramoplanin by forming a hydrophobic core buried within the U- 
shaped conformation of the natural product and may indirectly contribute to its properties. Significantly, the results with $\mathrm{Ala}^{17}$ indicate that this residue, and perhaps the adjoining residue $\mathrm{Ala}^{16}$, represent prime sites for modification or conjugation in efforts to probe ramoplanin's mechanism of action. Finally, it is similarly interesting and surprising that the conservative $\mathrm{Ala}^{15}$ replacement for Leu ${ }^{15}$ at the end of this region of the molecule resulted in a 20 -fold loss in antimicrobial activity.

\section{Discussion and Conclusions}

A full alanine scan of [Dap $\left.{ }^{2}\right]$ ramoplanin aglycon (6), a hydrolytically stable and slightly more potent analogue of the ramoplanin aglycon (5), was conducted providing insights into the importance and potential role of each residue. By far the most important residue in ramoplanin is D-Orn ${ }^{10}$. Its replacement with $\mathrm{Ala}^{10}$ resulted in a $>500$-fold reduction in antimicrobial activity consistent with its proposed integral role in Lipid II diphosphate binding. In contrast and more surprising to us, the conserved Orn ${ }^{4}$ was found to be substantially less important than Orn ${ }^{10}$ suggesting its role in binding Lipid I or II is not as critical. Both these residues lie in the putative recognition and binding domain proposed by McCafferty. ${ }^{8 \mathrm{a}}$ Two of the remaining residues in this region (residues 3-10) exhibit a larger impact than $\mathrm{Orn}^{4}\left(\mathrm{D}-\mathrm{Hpg}^{3}\right.$ and D$\left.\mathrm{Hpg}^{7}\right)$, a third is comparable $\left(a \mathrm{Thr}^{8}\right)$, and three appear much less important. Significantly, two of these (D- $\left.a \mathrm{Thr}^{5}, \mathrm{Hpg}^{6}\right)$ lie central to this putative Lipid II recognition domain and it is difficult to rationalize such a marginal impact central to a contiguous binding interface. An alternative explanation that might account for this behavior is that $\mathrm{Orn}^{4}$ may not be involved in Lipid I or II substrate binding, but rather that it may interact with the membrane phosphates and collaborate with the lipid side chain to deliver and anchor ramoplanin to the bacterial cell wall. In the monomer solution structure of ramoplanin, $\mathrm{Leu}^{15}, \mathrm{Ala}^{16}$, the lipid side chain and perhaps $\mathrm{Hpg}^{13} / \mathrm{Gly}^{14}$ form a hydrophobic face on one side of the molecule adjacent to $\mathrm{Orn}^{4}$ that could serve as the membrane binding domain, Figure 5. As such, the enduracidin's incorporation of End ${ }^{15}$ for ramoplanin's Leu ${ }^{15}$ would represent incorporation of an additional proximal membrane phosphate binding residue spatially bracketing this hydrophobic face of ramoplanin. The cluster of the remaining most prominent residues including $\operatorname{Orn}^{10}$ (red, >100-fold reduction) and D-Hpg ${ }^{3}, \mathrm{D}-\mathrm{Hpg}^{7}, a \mathrm{Thr}^{8}$, and $\mathrm{Hpg}^{11}$ (orange, $100-25$ fold reduction) traverses the opposite end of ramoplanin at one corner of its reverse $\beta$-turn at $a \mathrm{Thr}^{8}-\mathrm{Phe}^{9}$ potentially representing an alternative recognition domain for Lipid II. In the Walker's dimer structure, a potential and similar discontiguous recognition motif is defined by the red and orange residues and $\mathrm{Orn}^{4}$ is found proximal to the same hydrophobic face and lipid side chain. Although now speculative, such roles will become clearer upon examination of the derivatives herein for Lipid I or II binding in a transglycosylation inhibition assay that can dissect such roles. ${ }^{20}$

Within the residue 11-14 domain, all residues exhibit a significant effect even though they lie outside McCafferty's putative Lipid II recognition domain. The magnitude of their impact (1040 fold) suggest a prominent role in establishing ramoplanin's activity. Although there may be many explanations for this behavior, this would be consistent with their stabilization of the ramoplanin dimerization interface observed by Walker. ${ }^{6 \mathrm{e}}$ It is noteworthy that the most significant of these residues is $\mathrm{Hpg}^{11}$ which also lies adjacent to the critical $\mathrm{Orn}^{10}$ and is the site of glycosylation. Given the impact of $\mathrm{Hpg}^{11}$, it is possible that it plays a larger role in binding Lipid II than present models suggest.

One of the most interesting regions of the molecule spans residues 15-2. Attached to residue 2 is Asn ${ }^{1}$ which is external to the cyclic ring system and which is acylated with the unsaturated lipid side chain. We have suggested that this serves to anchor the antibiotic in the bacterial cell wall ensuring its localization at its site of action. ${ }^{20}$ Consistent with this, removal of the side chain or its replacement with a minimal acetyl group results in 200-800 fold reductions in antimicrobial activity, but has no effect on Lipid II binding or transglycosylase inhibition. ${ }^{20}$ 
This suggests that Leu ${ }^{15}-\mathrm{HAsn}^{2}$ resides adjacent to a membrane anchoring center where this region constitutes a "relatively" flexible loop at one end of the otherwise rigid U-shaped antiparallel $\beta$-sheet. As mentioned above, it is also possible that the proximal $\mathrm{Orn}^{4}$ collaborates with this lipid side chain by capping this membrane binding domain with a positively charged amine that binds membrane phosphates. We have also shown and continue to highlight herein, that $\mathrm{HAsn}^{2}$ may be effectively replaced with Dap ${ }^{2}$ providing a hydrolytically stable 49membered ring system in which an amide replaces the labile depsipeptide ester. The HAsn ${ }^{2}$ $\beta$-carboxamide clearly does not contribute to ramoplanin's interaction with its biological target (but may sterically hinder ester hydrolysis), and the $\mathrm{Dap}^{2}$ rigid secondary trans amide bond assuredly mimics the analogous trans ester conformation observed in the solution conformations of ramoplanin and enduracidin. Although flexible, efforts to expand ${ }^{19,20}$ or contract the macrocycle by a single carbon atom at this site have failed or resulted in nonfunctional compounds suggesting this region plays important conformationally-related roles helping to confine ramoplanin to productive conformations. With the possible exception of Leu ${ }^{15}$, the side chains of the remainder of this "flexible" loop, Leu ${ }^{15}$-D-Ala ${ }^{16}-\mathrm{Chp}^{17}$, do not appear to directly contribute to ramoplanin's antimicrobial activity. The surprisingly small impact of replacing $\mathrm{Chp}^{17}$ with $\mathrm{Ala}^{17}$ (4-fold), the disparate $\mathrm{Leu}^{15}$ versus solubilizing End ${ }^{15}$ residues found in the ramoplanins versus enduracidins, and the conserved minimal side chain at D-Ala ${ }^{16}$ not only suggest this "connecting" region of the molecule may represent a membrane interacting region of the molecule, but that it may be a good site for modification or conjugation studies.

Finally, the impact of nearly each residue is so significant that it is difficult to imagine deriving a simplified ramoplanin by excision of a substantial portion of its structure (i.e., cyclization or alternative presentations of only the putative recognition domain), $8 \mathrm{~b}$ the studies serve to define residues and regions amenable to further funtionalizations for detailed mechanistic studies in progress, and further insights into the individual roles of each residue may be forthcoming from their examination in assays establishing Lipid II binding or transglycosylation inhibition. ${ }^{20}$

\section{Supplementary Material}

Refer to Web version on PubMed Central for supplementary material.

\section{Acknowledgements}

We gratefully acknowledge the financial support of the National Institute of Health (CA41101) and the Skaggs Institute for Chemical Biology. We especially wish to thank Dr. Asad Chavoshi in Professor Ghadiri's Lab at the Scripps Research Institute for conducting the HF deprotection reactions.

\section{References}

1. Walsh CT. Nature 2000;406:775. [PubMed: 10963607]

2. (a) Pearson H. Nature 2002;418:469. [PubMed: 12152043] (b) von Nussbaum F, Brands M, Hinzen B, Weigand S, Häbich D. Angew Chem Int Ed 2006;45:5072.Review:

3. (a) Cavalleri B, Pagani H, Volpe G, Selva E, Parenti F. J Antibiot 1984;37:309. [PubMed: 6547132] (b) Pallanza R, Berti M, Scotti R, Randisi E, Arioli V. J Antibiot 1984;37:318. [PubMed: 6547133]

4. (a) Ciabatti R, Kettenring JK, Winters G, Tuan G, Zerilli L, Cavalleri B. J Antibiot 1989;42:254. [PubMed: 2597278] (b) Kettenring JK, Ciabatti R, Winters G, Tamborini G, Cavalleri B. J Antibiot 1989;42:268. [PubMed: 2925517]Reviews: (c) Walker S, Chen L, Hu Y, Rew Y, Shin D, Boger DL. Chem Rev 2005;105:449. [PubMed: 15700952] (d) Parenti F, Ciabatti R, Cavalleri B, Kettenring J. Drugs Exptl Clin Res 1990;16:451. [PubMed: 2100246] (e) McCafferty DG, Cudic P, Frankel BA, Barkallah S, Kruger RG, Li W. Biopolymers 2002;66:261. [PubMed: 12491539]

5. (a) Espersen F. Curr Opin Anti-Infect Invest Drugs 1999;1:78.Review: (b) Montecalvo MA. J Antimicrob Chemother 2003;51(Suppl S3):iii31. [PubMed: 12801940] 
6. (a) Somner EA, Reynolds PE. Antimicrob Agents Chemother 1990;34:413. [PubMed: 2334153] (b) Review: Reynolds PE, Somner EA. Drugs Exptl Clin Res 1990;16:385. [PubMed: 2151441] (c) Brötz H, Bierbaum G, Reynolds PE, Sahl H-G. Eur J Biochem 1997;246:193. [PubMed: 9210483] (d) Lo MC, Men H, Branstrom A, Helm J, Yao N, Goldman R, Walker S. J Am Chem Soc 2000;122:3540. (e) Lo MC, Helm JS, Sarngadharan G, Pelczer I, Walker S. J Am Chem Soc 2001;123:8640. [PubMed: 11525690] (f) Helm JS, Chen L, Walker S. J Am Chem Soc 2002;124:13970. [PubMed: 12440876] (g) Hu Y, Helm JS, Chen L, Ye XY, Walker S. J Am Chem Soc 2003;125:8736. [PubMed: 12862463]

7. Reviews: (a) Barna JCJ, Williams DH. Ann Rev Microbiol 1984;38:339. [PubMed: 6388496] (b) Williams DH, Bardsley B. Angew Chem Int Ed 1999;38:1172.

8. (a) Cudic P, Kranz JK, Behenna DC, Kruger RG, Tadesse H, Wand AJ, Veklich YI, Weisel JW, McCafferty DG. Proc Natl Acad Sci USA 2002;99:7384. [PubMed: 12032292] (b) Cudic P, Behenna DC, Kranz JK, Kruger RG, Wand AJ, Veklich YI, Weisel JW, McCafferty DG. Chem Biol 2002;9:897. [PubMed: 12204689]

9. Jones RN, Barry AL. Diagn Microbiol Infect Dis 1989;12:279. [PubMed: 2507218]

10. Kurz M, Guba W. Biochemistry 1996;35:12570. [PubMed: 8823194]

11. Skelton NJ, Harding MM, Mortishire-Smith RJ, Rahman SK, Williams DH, Rance MJ, Ruddock JC. J Am Chem Soc 1991;113:7522.

12. (a) Higashide E, Hatano K, Shibata M, Nakazawa K. J Antibiot 1968;21:126. [PubMed: 5674368] (b) Asai M, Muroi M, Sugita N, Kawashima H, Mizuno K, Miyake A. J Antibiot 1968;21:138. [PubMed: 5674369] (c) Tsuchiya K, Takeuchi Y. J Antibiot 1968;21:426. [PubMed: 5723085] (d) Hori M, Iwasaki H, Horii S, Yoshida I, Hongo T. Chem Pharm Bull 1973;21:1175. (e) Iwasaki H, Horii S, Asai M, Mizuno K, Ueyanagi J, Miyake A. Chem Pharm Bull 1973;21:1184. (f) Fang X, Tiyanont K, Zhang Y, Wanner J, Boger D, Walker S. Mol BioSyst 2006;2:69. [PubMed: 16880924]

13. Castiglione F, Marazzi A, Meli M, Colombo G. Magn Reson Chem 2005;43:603. [PubMed: 15986494]

14. (a) Meyers E, Weisenborn FL, Pansy FE, Slusarchyk DS, von Saltza MH, Rathnum ML, Parker WL. J Antibiot 1970;23:502. [PubMed: 5482761] (b) Linnett PE, Strominger JL. Antimicrob Agents Chemother 1973;4:231. [PubMed: 4202341]

15. (a) Jiang W, Wanner J, Lee RJ, Bounaud PY, Boger DL. J Am Chem Soc 2002;124:5288. [PubMed: 11996568] (b) Jiang W, Wanner J, Lee RJ, Bounaud PY, Boger DL. J Am Chem Soc 2003;125:1877. [PubMed: 12580615] (c) Review: Boger DL. Med Res Rev 2001;21:356-381. [PubMed: 11579438]

16. (a) Nonpolar solvents $\left(\mathrm{CH}_{2} \mathrm{Cl}_{2}, \mathrm{CHCl}_{3}, \mathrm{EtOAc}\right)$ should be used to take advantage of the $\beta$-sheet preorganization. However, the linear substrates typically proved insoluble in such solvents. Consequently, variable amounts of DMF are added until the substrates were dissolved. Maplestone RA, Cox JPL, Williams DH. FEBS Lett 1993;326:95. [PubMed: 8325394]

17. (a) Rich DH, Bhatnagar P, Mathiaparanam P, Grant JA, Tam JP. J Org Chem 1978;43:296. [PubMed: 621598] (b) Brady SF, Varga SL, Freidinger RM, Schwenk DA, Mendlowski M, Holly FW, Veber DF. J Org Chem 1979;44:3101.

18. Shin D, Rew Y, Boger DL. Proc Natl Acad Sci USA 2004;101:11977. [PubMed: 15175429]

19. Rew Y, Shin D, Hwang I, Boger DL. J Am Chem Soc 2004;126:1041. [PubMed: 14746470]

20. Chen L, Yuan Y, Helm JS, Hu Y, Rew Y, Shin D, Boger DL, Walker S. J Am Chem Soc 2004;126:7462. [PubMed: 15198592]

21. (a) Brötz H, Bierbaum G, Leopold K, Reynolds PE, Sahl H-G. Antimicrob Agents Chemother 1998;42:154. [PubMed: 9449277] (b) Brötz H, Josten M, Wiedemann I, Schneider U, Gotz F, Bierbaum G, Sahl H-G. Mol Microbiol 1998;30:317. [PubMed: 9791177]

22. Chen Y, Bilban M, Foster CA, Boger DL. J Am Chem Soc 2002;124:5431. [PubMed: 11996584]

23. EDCI = 1-(3-dimethylaminopropyl)-3-ethylcarbodiimide hydrochloride, HOAt $=1$-hydroxy-7azabenzotriazole, DEPBT = 3-(diethoxyphosphoryloxy)-1,2,3-benzotriazin-4(3H)-one, SES = 2trimethylsilylethanesulfonyl, $\mathrm{BCB}=B$-bromocatecholborane.

24. In contrast, removal of the aromatic chlorines from vancomycin diminishes dimerization and altered its antimicrobial activity. See: (a) Harris CM, Kannan R, Kopecka H, Harris TM. J Am Chem Soc 1985;107:6652. (b) Gerhard U, Mackay JP, Maplestone RA, Williams DH. J Am Chem Soc $1993 ; 115: 232$. 
3

(1)

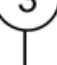

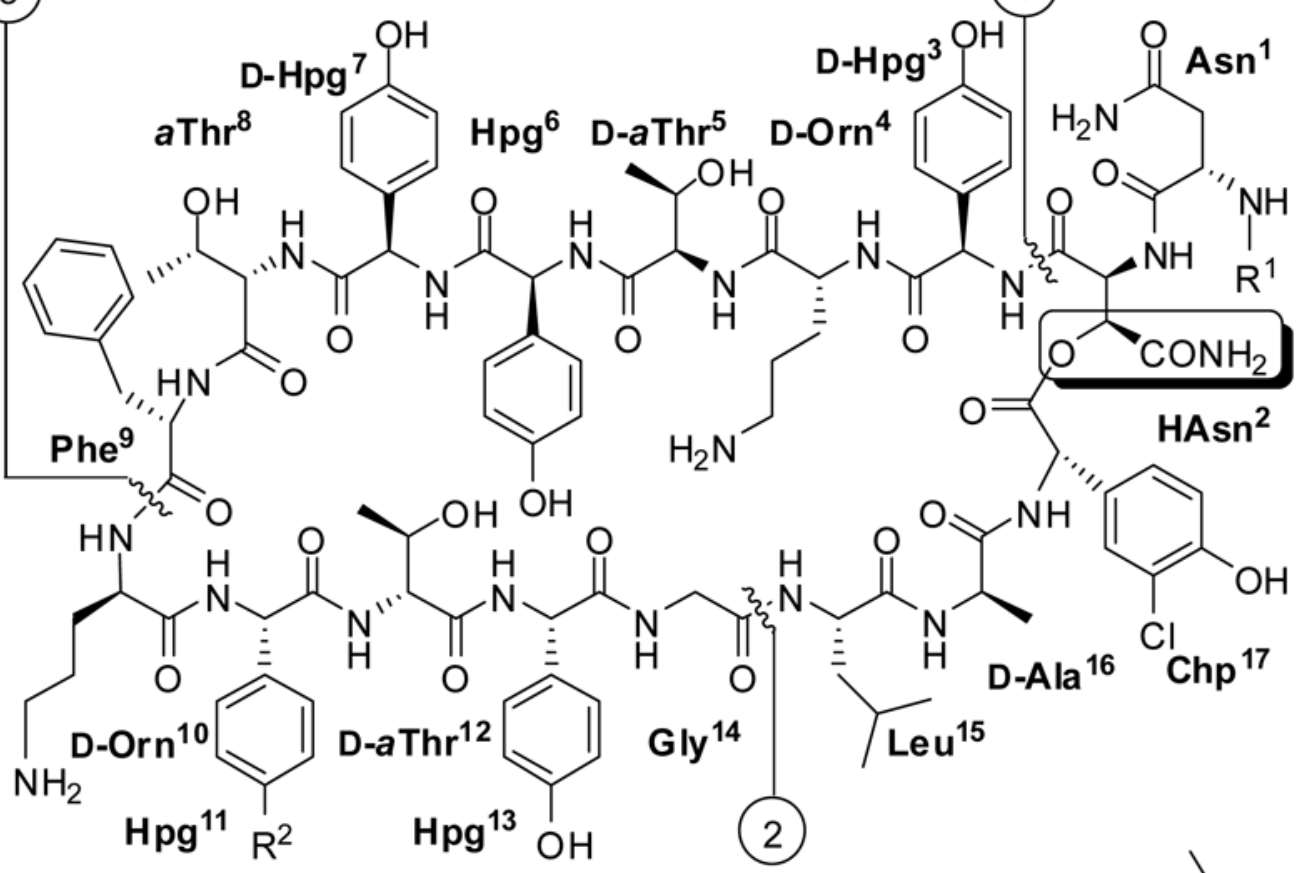<smiles>[R]=[R]CC(=O)/C=C\C=C/CCC</smiles>

Ramoplanin A1 (1)

Ramoplanin A2 (2)

Ramoplanin A3 (3)

$\mathrm{R}^{2}=\mathrm{OH}, 5$

Ramoplanin Aglycon
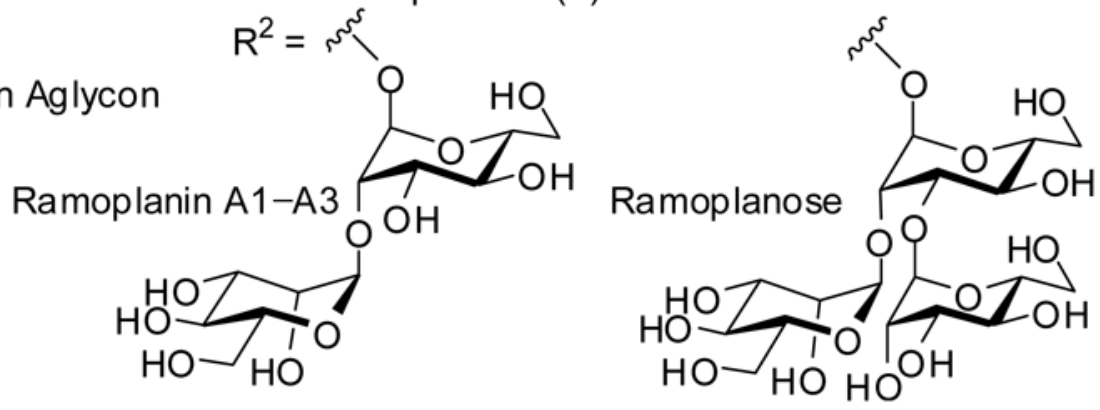

Figure 1.

Structure of the ramoplanins. 


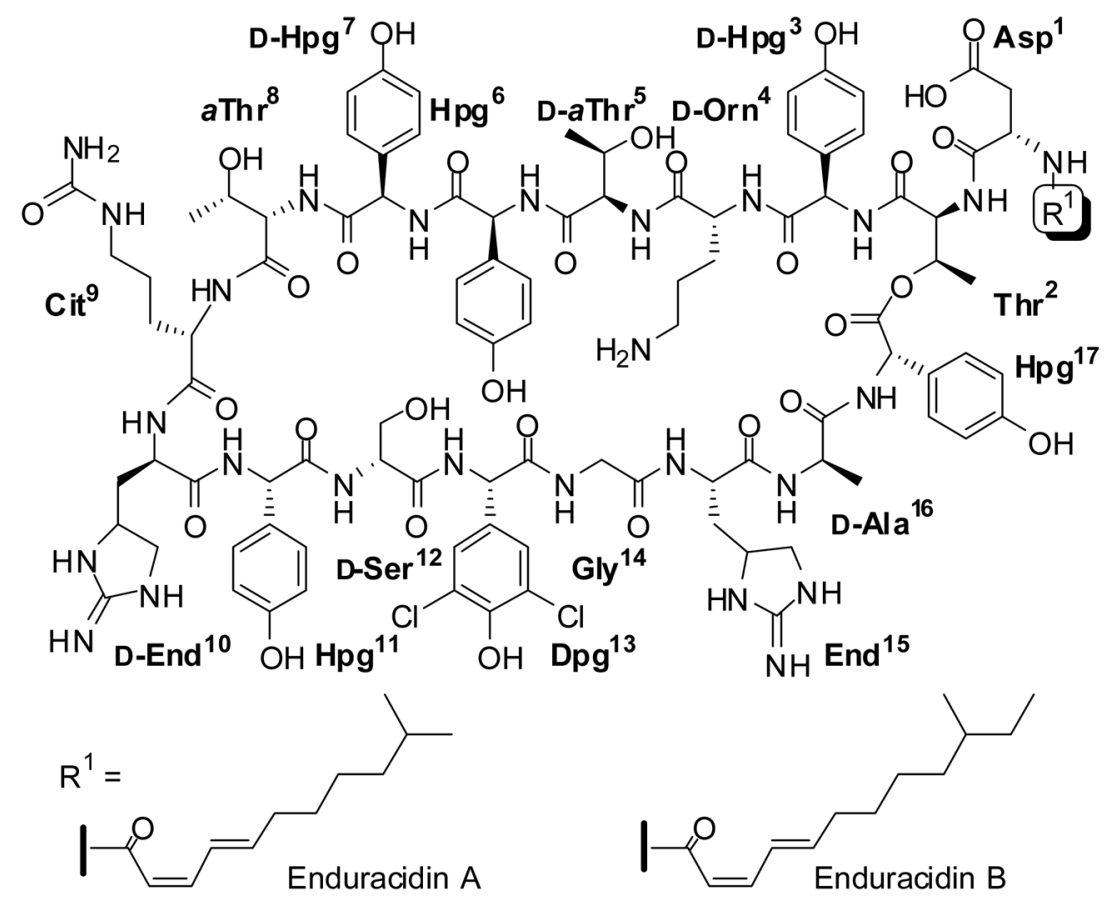

Figure 2.

Structures of the enduracidins. 

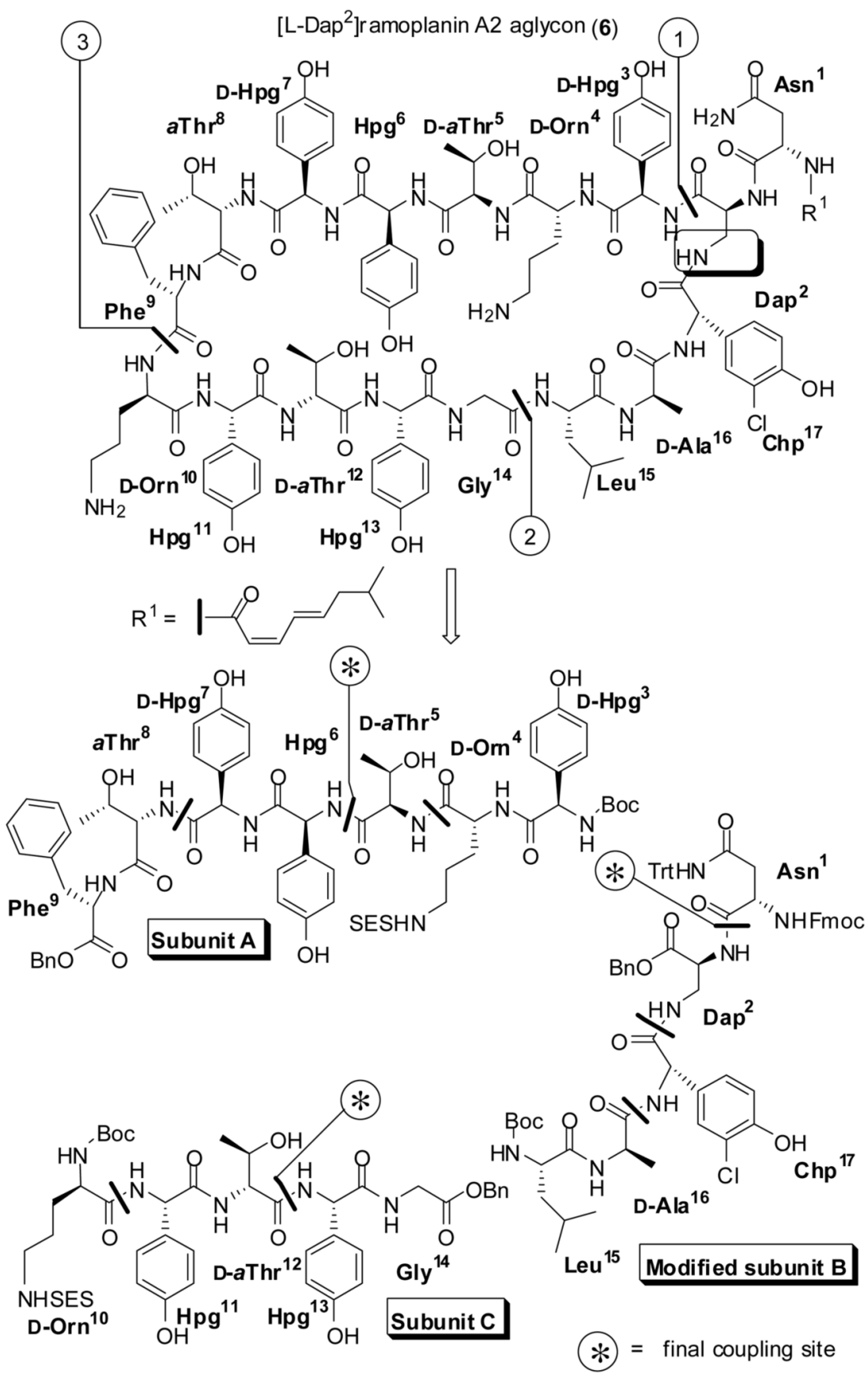

Figure 3.

Structure of [Dap ${ }^{2}$ ramoplanin A2 aglycon (6) and the three key subunits A-C. 


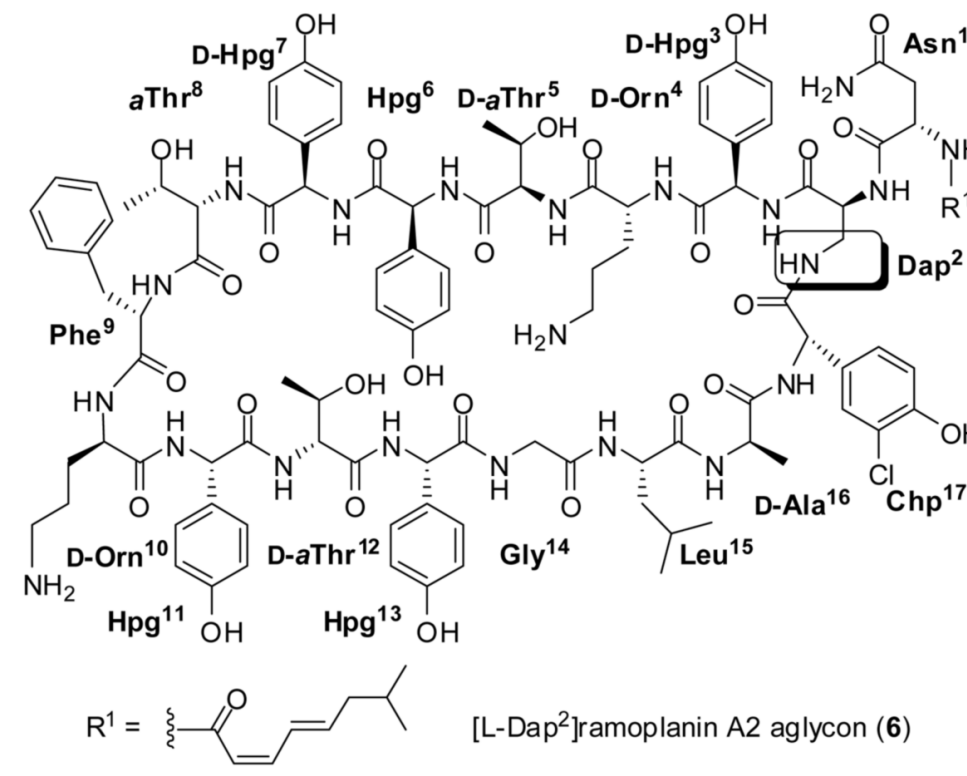

\begin{tabular}{|c|c|c|c|}
\hline Compound & $\begin{array}{l}\text { Authentic } \\
\text { residue }\end{array}$ & $\begin{array}{c}\text { MIC } \\
(\mu \mathrm{g} / \mathrm{mL})^{\mathrm{a}, \mathrm{b}}\end{array}$ & $\begin{array}{c}\text { Fold } \\
\text { difference }\end{array}$ \\
\hline ramoplanin complex $\mathbf{1 - 3}$ & & 0.19 & 2.7 \\
\hline 5 , ramoplanin $\mathrm{A} 2$ aglycon & & 0.11 & 1.6 \\
\hline 6, [Dap ${ }^{2}$ ]ramoplanin A2 aglycon & & 0.07 & 1 \\
\hline $\mathbf{8 g},\left[\mathrm{Dap}^{2}, \mathrm{D}-\mathrm{Ala}^{3}\right]$ ramoplanin A2 aglycon & D-Hpg ${ }^{3}$ & 5.2 & 74 \\
\hline 9g, $\left[\mathrm{Dap}^{2}, \mathrm{D}-\mathrm{Ala}^{4}\right]$ ramoplanin A2 aglycon & D-Orn ${ }^{4}$ & 3.1 & 44 \\
\hline 10g, $\left[\mathrm{Dap}^{2}, \mathrm{D}-\mathrm{Ala}{ }^{5}\right] \mathrm{ramoplanin} \mathrm{A} 2$ aglycon & D-aThr ${ }^{5}$ & 0.16 & 2.3 \\
\hline 11g, $\left[\mathrm{Dap}^{2}, \mathrm{Ala}^{6}\right]$ ramoplanin $\mathrm{A} 2$ aglycon & $\mathrm{Hpg}^{6}$ & 0.9 & 13 \\
\hline $12 \mathrm{~g},\left[\mathrm{Dap}^{2}, \mathrm{D}-\mathrm{Ala}^{7}\right]$ ramoplanin A2 aglycon & $\mathrm{D}-\mathrm{Hpg}^{7}$ & 3.7 & 53 \\
\hline 13g, [Dap $\left.{ }^{2}, \mathrm{Ala}^{8}\right]$ ramoplanin A2 aglycon & $a T h r^{8}$ & 2.5 & 36 \\
\hline 14g, $\left[\mathrm{Dap}^{2}, \mathrm{Ala}^{9}\right]$ ramoplanin $\mathrm{A} 2$ aglycon & $\mathrm{Phe}^{9}$ & 0.6 & 8.6 \\
\hline $16 \mathrm{~g},\left[\mathrm{Dap}^{2}, \mathrm{D}-\mathrm{Ala}^{10}\right]$ ramoplanin A2 aglycon & $\mathrm{D}-\mathrm{Orn}{ }^{10}$ & 38 & 540 \\
\hline $17 \mathbf{g},\left[\mathrm{Dap}^{2}, \mathrm{Ala}^{11}\right]$ ramoplanin $\mathrm{A} 2$ aglycon & $\mathrm{Hpg}^{11}$ & 2.5 & 36 \\
\hline 18g, $\left[\mathrm{Dap}^{2}, \mathrm{D}-\mathrm{Ala}^{12}\right]$ ramoplanin A2 aglycon & D-aThr ${ }^{12}$ & 0.7 & 10 \\
\hline $19 \mathrm{~g},\left[\mathrm{Dap}^{2}, \mathrm{Ala}^{13}\right.$ ramoplanin $\mathrm{A} 2$ aglycon & $\mathrm{Hpg}^{13}$ & 1.4 & 20 \\
\hline $\mathbf{2 1 g},\left[\mathrm{Dap}^{2}, \mathrm{Ala}^{15}\right]$ ramoplanin $\mathrm{A} 2$ aglycon & Leu $^{15}$ & 1.4 & 20 \\
\hline 22g, [Dap ${ }^{2}, \mathrm{Ala}^{17}$ ]ramoplanin A2 aglycon & Chp $^{17}$ & 0.3 & 4 \\
\hline 23g, $\left[\mathrm{Dap}^{2}, \mathrm{Hpg}^{17}\right]$ ramoplanin A2 aglycon & Chp ${ }^{17}$ & 0.09 & 1.3 \\
\hline
\end{tabular}

a MIC values $(\mu \mathrm{g} / \mathrm{mL})$ were obtained using a standard microdilution assay. The MIC is defined as the lowest antibiotic concentration that resulted in no visible growth after incubation at $37^{\circ} \mathrm{C}$ for $24 \mathrm{~h}$.

${ }^{b}$ Bacterial strain S. aureus ATCC 25923.

Figure 4.

Antimicrobial minimum inhibitory concentrations (MIC). 

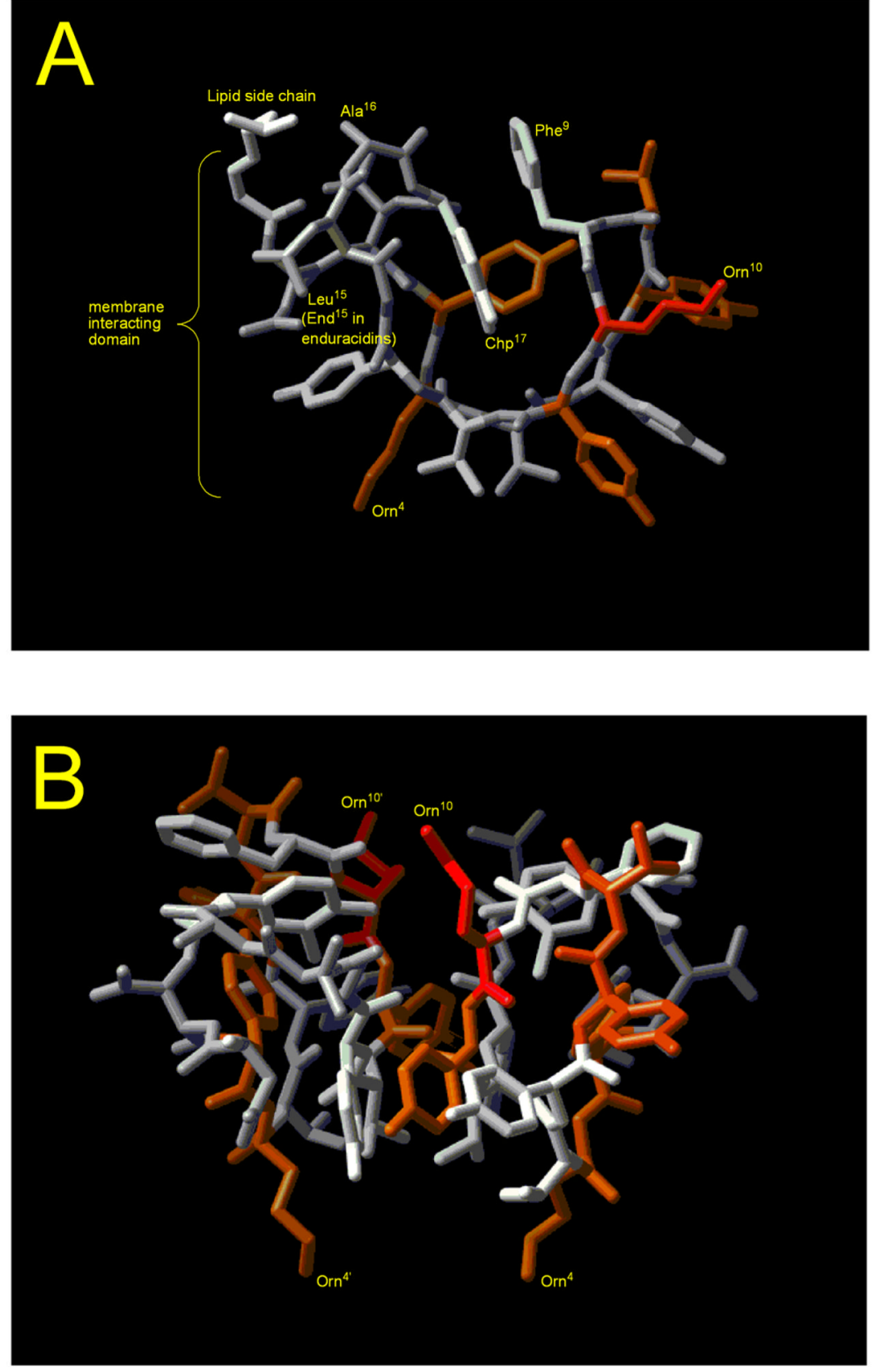

Figure 5.

(A) Monomer and (B) dimer solution structures of ramoplanin (red: >100, orange: 100-25, white: $<25$-fold reductions in antimicrobial activity by alanine scan). 


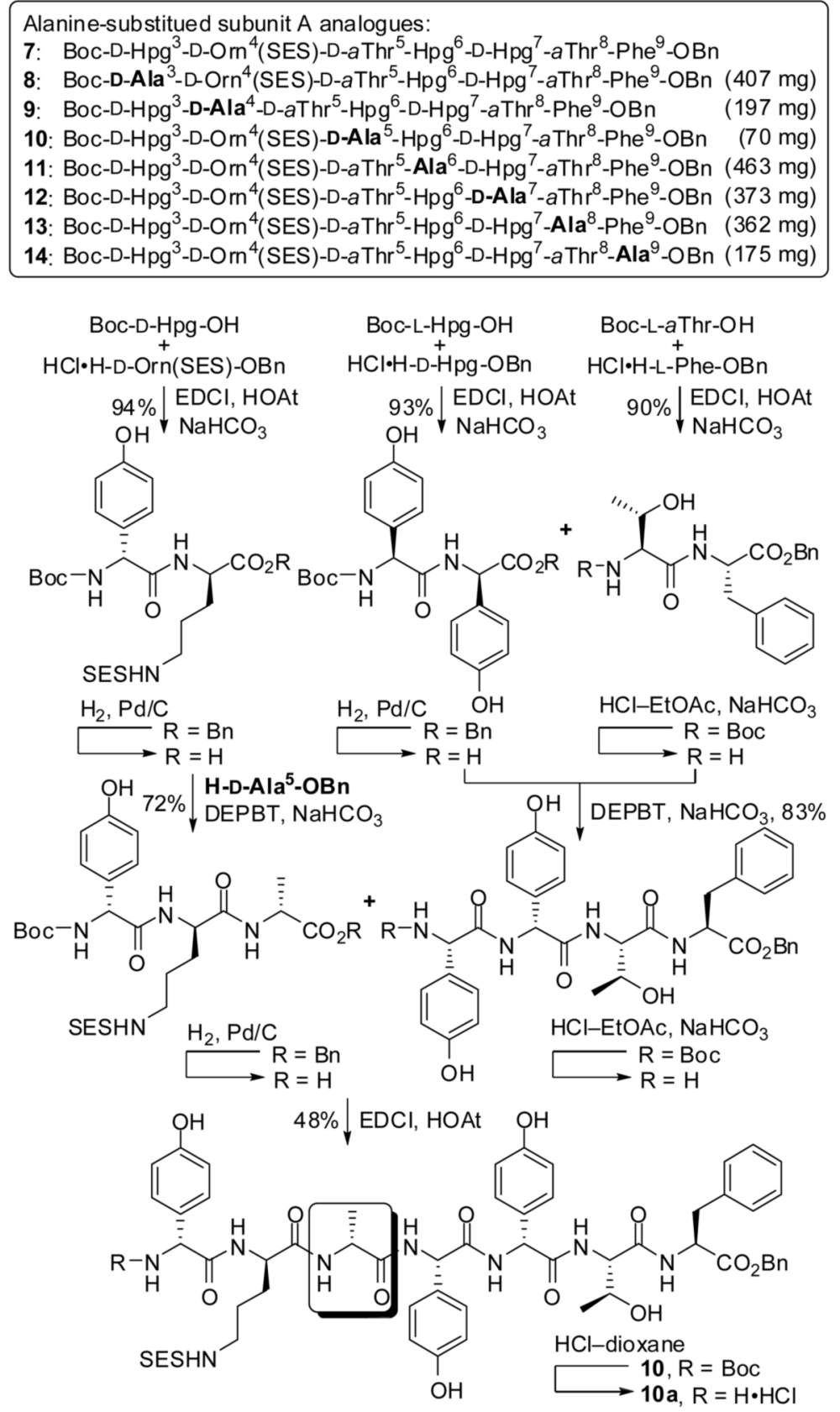

10: Boc-D-Hpg ${ }^{3}-\mathrm{D}-\mathrm{Orn}^{4}(\mathrm{SES})-\mathrm{D}-\mathrm{Ala}^{5}-\mathrm{Hpg}^{6}-\mathrm{D}-\mathrm{Hpg}^{7}-\mathrm{aThr}^{8}-\mathrm{Phe}^{9}-\mathrm{OBn}$

Scheme 1.

23 Alanine-substituted subunit A analogues and synthesis of $\left[\mathrm{Ala}^{5}\right]$ subunit A (10). 


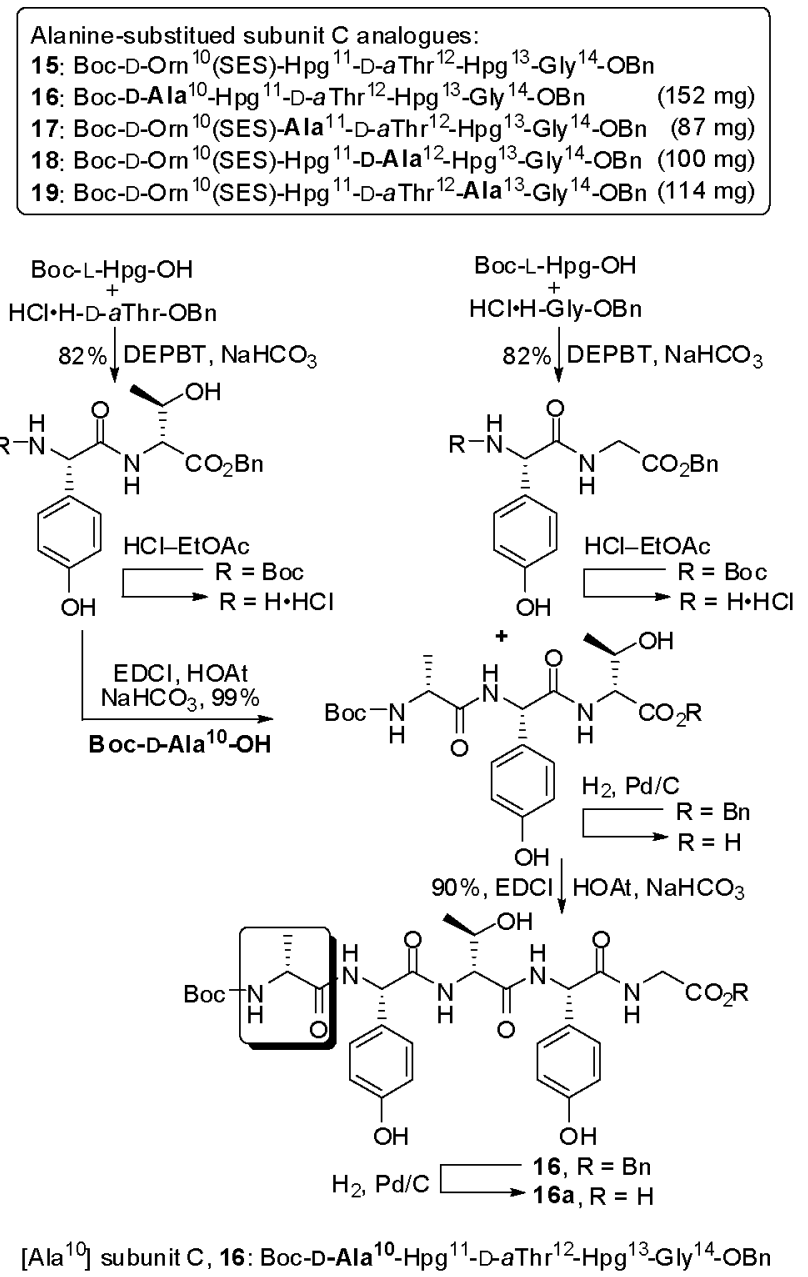

Scheme 2.

23 Alanine-substituted subunit $\mathrm{C}$ analogues and synthesis of $\left[\mathrm{Ala}^{10}\right]$ subunit $\mathrm{C}(\mathbf{1 6})$. 


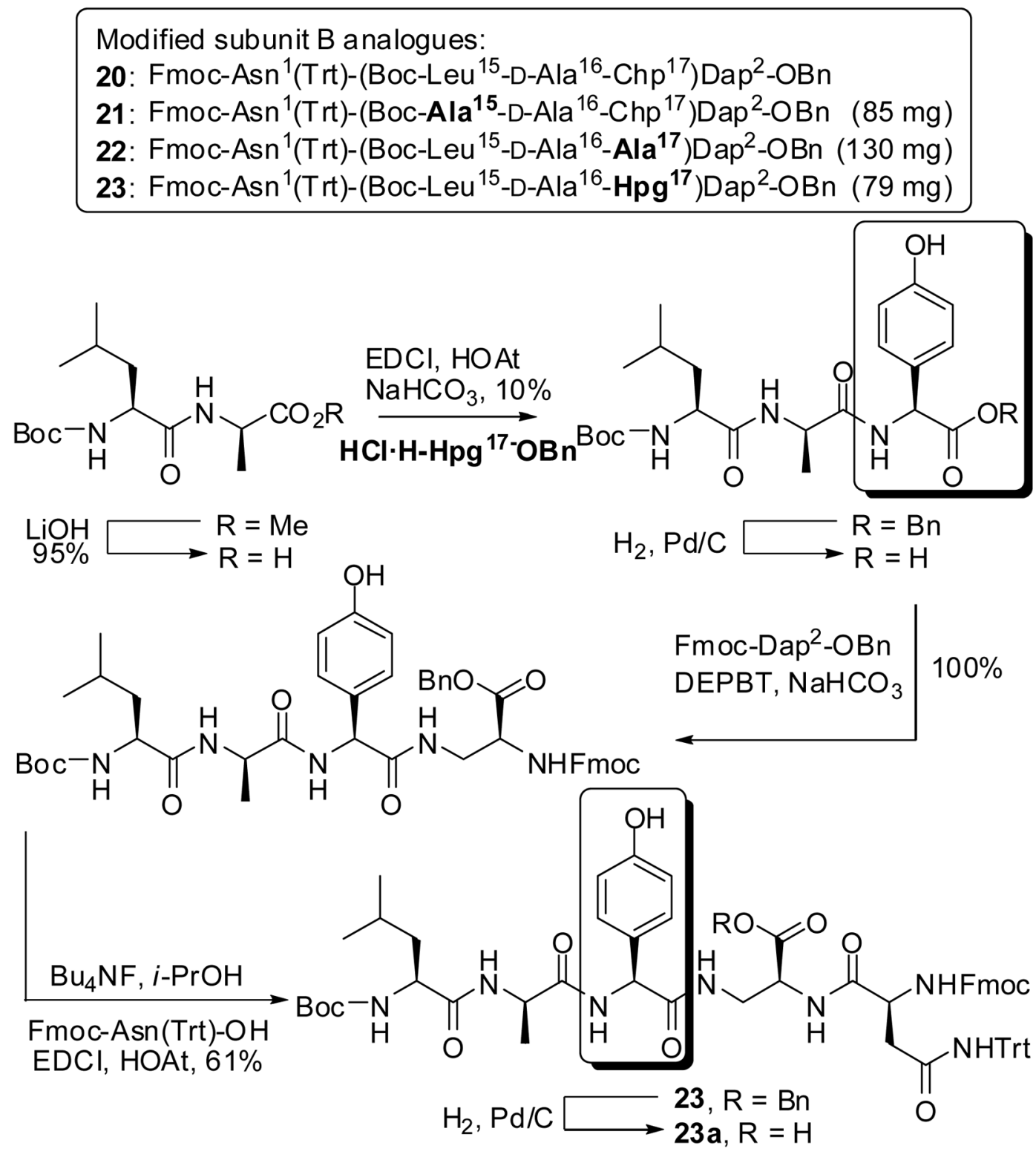

23: Fmoc-Asn ${ }^{1}$ (Trt)-(Boc-Leu $\left.{ }^{15}-\mathrm{D}-\mathrm{Ala}^{16}-\mathrm{Hpg}^{17}\right)-\mathrm{Dap}^{2}-\mathrm{OBn}$

Scheme 3.

${ }^{23}$ Modified subunit B and its analogues. 

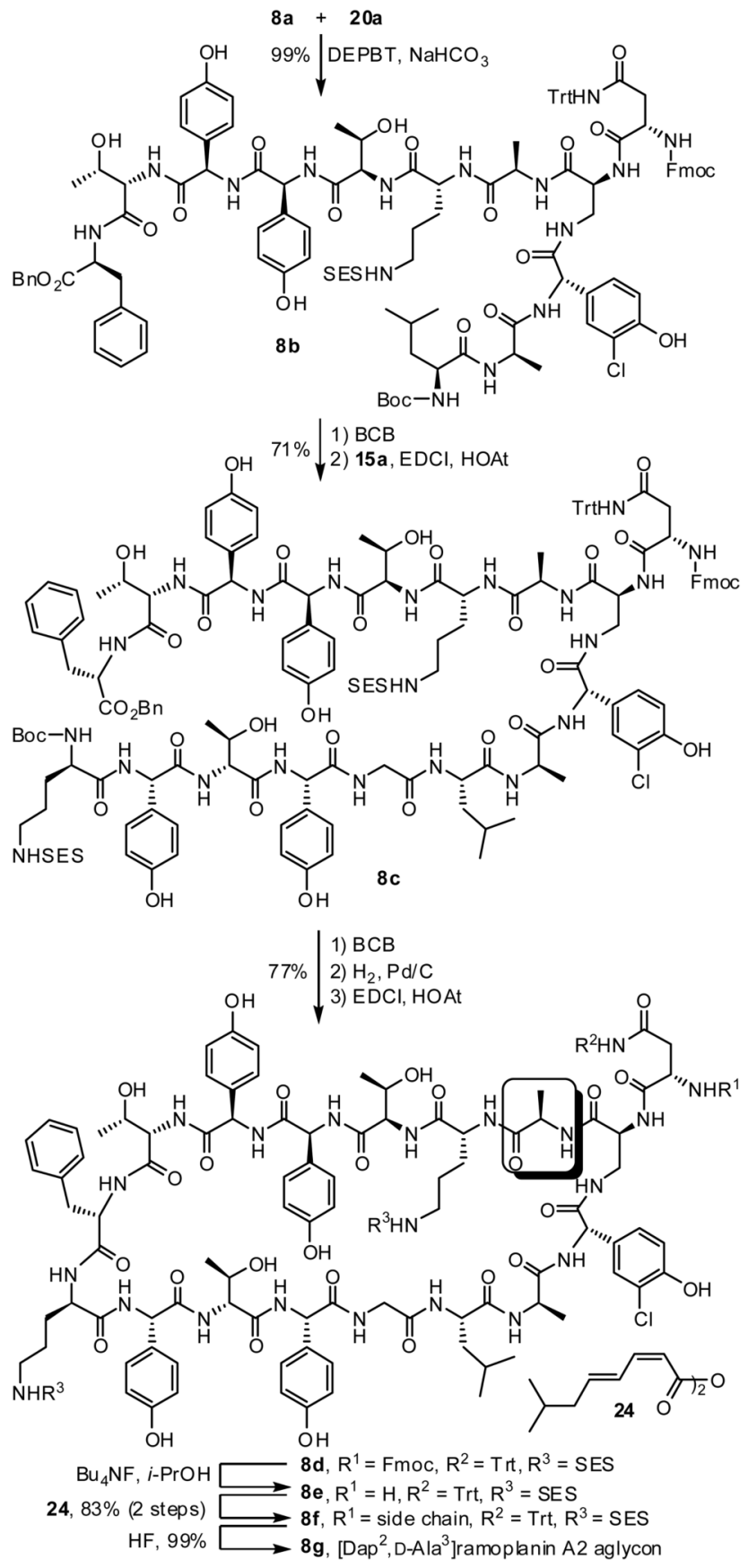

Scheme 4.

${ }^{23}$ Synthesis of [Dap $\left.{ }^{2}, \mathrm{Ala}^{3}\right]$ ramoplanin A2 aglycon $(\mathbf{8 g})$. 

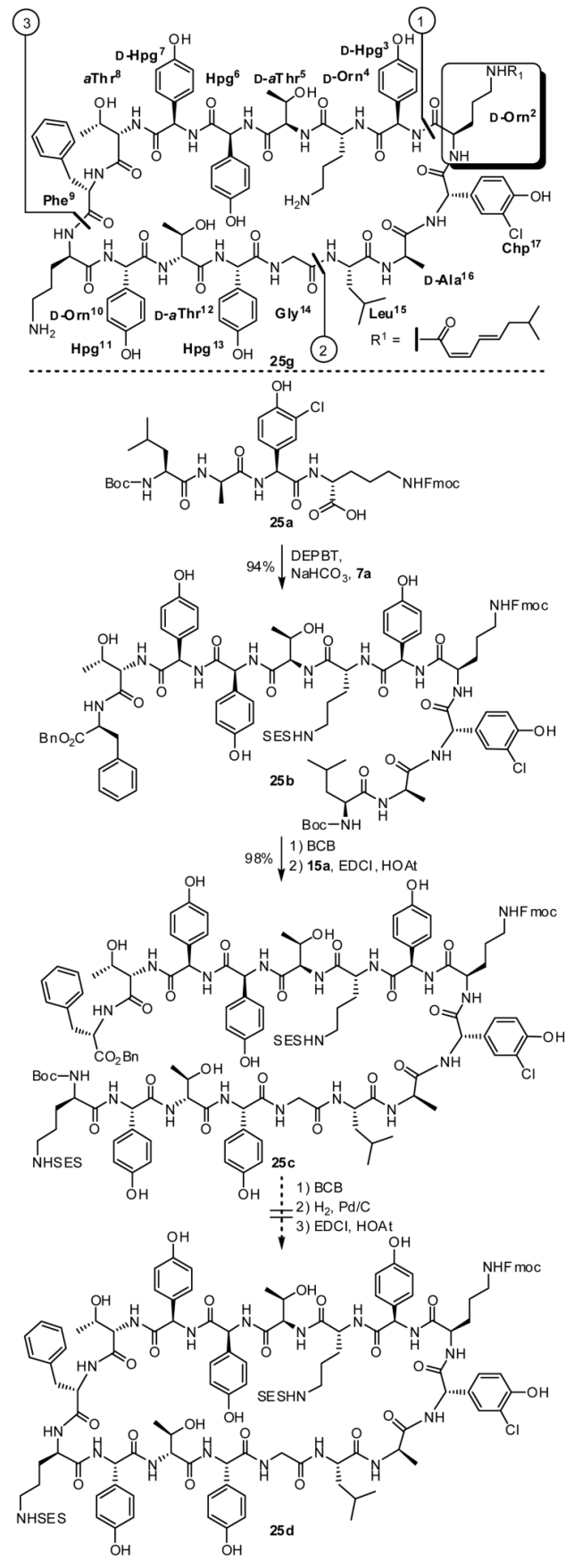

Scheme 5.

Attempted synthesis of the 48-membered [D-Orn ${ }^{2}$ ]ramoplanin A2 aglycon (25g). 